\title{
OPTIC NERVE SHEATH SONOGRAPHY IS A PROMISING TOOL FOR ASSESSMENT OF RAISED INTRACRANIAL PRESSURE IN PATIENTS ADMITTED TO NEUROLOGICAL INTENSIVE CARE UNIT
}

\author{
Arijana Lovrenčić-Huzjan ${ }^{1,2,3}$, Marijana Bosnar-Puretić1,2, Ivana Hustić ${ }^{1,2}$, Ivana Kobasić ${ }^{1,2}$, \\ Mislav Budišići, ${ }^{1,2}$ Lejla Ćorićc ${ }^{1,2}$ and Marina Roje-Bedekovićc ${ }^{1,2}$ \\ ${ }^{1}$ Department of Neurology, Sestre milosrdnice University Hospital Centre, Zagreb, Croatia; \\ ${ }^{2}$ University of Zagreb, School of Medicine, Zagreb, Croatia; \\ ${ }^{3}$ University of Zagreb, School of Dental Medicine, Zagreb, Croatia
}

\begin{abstract}
SUMMARY - Optic nerve sheath diameter (ONSD) enlargement is detectable in traumatic brain injury patients with raised intracranial pressure (ICP). The aim was to assess its value in neurological patients suspected to have increased ICP. Patient clinical imaging data and hospitalization outcome were analyzed. Patients were divided into groups according to brain pathology and level of consciousness with Glasgow Coma Score (GCS). Poor hospitalization outcome was assessed by modified Rankin scale $(\mathrm{mRS})>3$. Data obtained by ocular sonography performed in acute setting were compared with data of 100 control subjects. Data were expressed as mean \pm SD. Intergroup comparison was performed by Student's t-test. Data of 34 patients $(63 \pm 16$ years) were suitable for analysis, including 8 primary intracerebral hemorrhage (PICH), 8 subarachnoid hemorrhage (SAH), $12 \mathrm{PICH}$ or SAH and intraventricular hemorrhage (IVH), 4 tumors and 2 ischemic strokes. The mean ONSD was $5.86 \pm 0.69 \mathrm{~mm}$ in patients versus $4.38 \pm 0.41 \mathrm{~mm}$ in controls $(\mathrm{p}<0.01)$. ONSD was $6.28 \pm 0.61 \mathrm{~mm}$ in patients with GCS $<8$ and $5.77 \pm 0.55 \mathrm{~mm}$ in other patients $(\mathrm{p}<0.05)$. ONSD was $5.72 \pm 0.59 \mathrm{~mm}$ in $\mathrm{PICH}$ versus $6.20 \pm 0.65 \mathrm{~mm}$ in $\mathrm{PICH} / \mathrm{SAH}$ with IVH $(\mathrm{p}=0.1)$. ONSD was $5.73 \pm 0.38 \mathrm{~mm}$ in $\mathrm{SAH}$ in comparison to $\mathrm{PICH} / \mathrm{SAH}$ with IVH $(\mathrm{p}=0.05)$. There was no statistically significant difference in optic nerve diameter between patients and controls $(2.48 \pm 0.28 \mathrm{~mm}$ vs. $2.39 \pm 0.33 \mathrm{~mm} ; \mathrm{p}>0.05)$. Pronounced enlargement of ONSD was observed in patients with ICH or SAH with IVH, and in patients with GCS $<8$. Enlarged ONSD was associated with poor neurological outcome ( $\mathrm{mRS}>3$ ).
\end{abstract}

Key words: Optic nerve; Brain injuries, traumatic; Intracranial pressure; Ultrasonography

\section{Introduction}

Detection of raised intracranial pressure (ICP) is associated with poor outcome of patients in neurocritical care. Although invasive ventricular devices are the

Correspondence to: Arijana Lovrenčic-Huzjan, Department of Neurology, Sestre milosrdnice University Hospital Centre, Vinogradska c. 29, HR-10000 Zagreb, Croatia

E-mail: arijana.huzjan@gmail.com; arijana.lovrencic-huzjan@zg.t-com.hr

Received December 3, 2018, accepted April 16, 2019 gold standard for continuous and reliable measurement of ICP in traumatic brain injury (TBI), their placement could be challenging due to the lack of immediate surgical availability, hematologic contraindication for its placement, and possibility of malfunction or obstruction. Raised ICP is not rare in stroke, but these patients are usually managed without invasive ICP monitoring. Noninvasive evaluation of ICP relies on clinical symptoms that are lacking in sedated patients, or repeated computed tomography (CT) or 
magnetic resonance imaging (MRI) scanning for monitoring complications of raised ICP such as edema, midline shift or herniation.

As part of the central nervous system, optic nerve is surrounded by cerebrospinal fluid and by meninges designated as optic nerve sheath. Different studies demonstrated that raised ICP led to enlargement of the optic nerve sheath diameter (ONSD) ${ }^{1,2}$. Such changes can be reliably measured by MRI or transorbital ultrasonography ${ }^{1-3}$. Due to technical reasons and high costs, MRI is rarely undertaken in these settings. Fundus changes are a noninvasive assessment method of optic disk edema, but displays changes several days after the onset of ICP elevation.

Transorbital ultrasonography has been demonstrated to be a reliable bedside technique for noninvasive detection of elevated ICP in $\mathrm{TBI}^{4-7}$, post resuscitation syndrome ${ }^{8}$, or infection. It was shown to be a useful tool in the assessment of patients with primary or secondary idiopathic intracranial hypertension ${ }^{9}$, intracranial hypotension ${ }^{10}$, and in two studies it was used in the assessment of stroke patients ${ }^{11,12}$. It was employed to monitor patients after placement of an extraventricular drain in subarachnoid hemorrhage (SAH) and acute hydrocephalus, but no relevant decline of ONSD could be measured over time ${ }^{13}$. For monitoring beyond the hyperacute stage of intracerebral hemorrhage (ICH), ONSD correlated with midline shift of the third ventricle on $\mathrm{CT}$ scans ${ }^{14}$. It is a feasible test to discriminate brain dead persons from healthy controls ${ }^{15}$, and can help in monitoring of sedated patients in neurocritical care ${ }^{16}$.

The aim of this study was to assess the value of ONSD enlargement in patients admitted to the neurological intensive care unit (NICU) suspected to have raised ICP.

\section{Patients and Methods}

Data on 37 consecutive patients admitted to the NICU in the period from June 1, 2015 until December 31, 2015 due to neurologic emergency and submitted to ocular sonography within 48 hours of hospital admission were analyzed. Patients were admitted to NICU due to impaired consciousness, vomiting or emergency CT findings of brain pathology that might have a life-threatening course (e.g., hemorrhage, major ischemic stroke). Invasive ICP monitoring was not

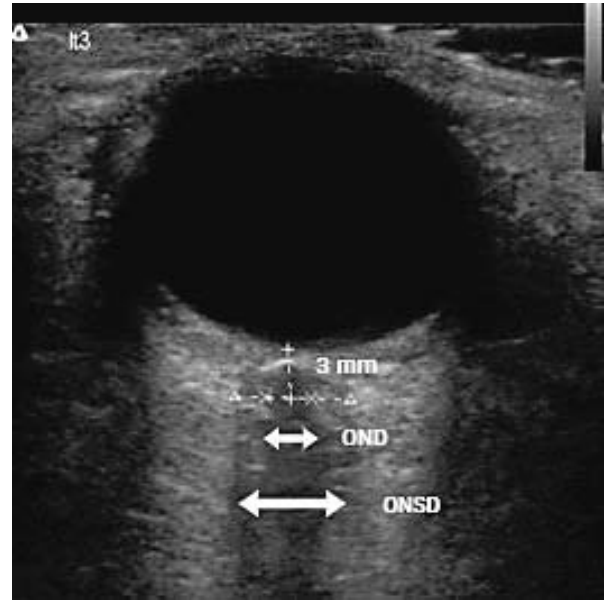

Fig. 1. Measurement of optic nerve sheath diameter and optic nerve diameter.

ONSD = optic nerve sheath diameter; $\mathrm{OND}=$ optic nerve diameter

routinely undertaken in these patients. Patient demographic and clinical data, brain pathology as the reason for admission, data on ocular nerve sonography and hospitalization outcome were retrieved from patient charts. The study was approved by the institutional ethics committee.

Data on 34 patients were suitable for analysis. Data on acute CT scans were analyzed for assessment of brain pathology. Patients with primary intracerebral hemorrhage (PICH), SAH, tumor and ischemic stroke were included in the analysis. The presence of intraventricular hemorrhage (IVH) was noted. Level of consciousness was assessed with Glasgow Coma Score (GCS). Coma was rated as GCS $<8$. Patients were divided into groups according to brain pathology and level of consciousness. Hospitalization outcome was assessed by modified Rankin scale (mRS), with favorable outcome of $\mathrm{mRS} \leq 3$.

Ocular sonography was performed with $12 \mathrm{MHz}$ linear ultrasound probe (Terason T3000, Teratech Corporation, USA) with reduced acoustic power (mechanical index 0.2). The probe was adjusted to give a suitable angle for displaying the optic nerve entry into the globe, at the depth of $3 \mathrm{~mm}$ behind the globe. Right and left optic nerves were measured in transverse plane, with slight rotation of the probe to obtain better optic nerve visualization. For each optic nerve, ONSD and optic nerve diameter (OND) were measured twice (Fig. 1). Control group consisted of 100 healthy individuals assessed by ocular sonography. 
Patient demographic data and level of consciousness were presented descriptively. Data on OND and ONSD for each group of brain pathology and level of consciousness were expressed as mean and SD. Student's t-test was used on comparison of patients and controls, and on intergroup comparison of different brain pathologies and hospitalization outcomes. The level of statistical significance was set at $\mathrm{p}<0.05$.

\section{Results}

The mean ONSD was $5.86 \pm 0.69 \mathrm{~mm}$ in patients admitted to NICU and $4.38 \pm 0.41 \mathrm{~mm}$ in controls $(\mathrm{p}<0.01)$. The mean OND was $2.48 \pm 0.28 \mathrm{~mm}$ in $\mathrm{pa}^{-}$ tients and $2.39 \pm 0.33 \mathrm{~mm}$ in controls $(\mathrm{p}>0.05)$ (Table 1$)$.

Data on 34 patients (19 males), mean age $63 \pm 16$ years, suitable for analysis are shown in Table 2 . There were eight patients with $\mathrm{PICH}$, eight with $\mathrm{SAH}, 12$

Table 1. Comparison of ocular sonography between patients admitted to intensive care unit and controls

\begin{tabular}{|l|l|l|}
\hline & $\begin{array}{l}\text { Patients admitted to } \\
\text { intensive care unit } \\
\mathrm{N}=34\end{array}$ & $\begin{array}{l}\text { Controls } \\
\mathrm{N}=100\end{array}$ \\
\hline $\begin{array}{l}\text { Optic nerve } \\
\text { diameter }(\mathrm{mm}) \\
\text { Mean } \pm \mathrm{SD}\end{array}$ & $2.48 \pm 0.28$ & $2.39 \pm 0.33$ \\
$\begin{array}{l}\text { Optic nerve sheath } \\
\text { diameter }(\mathrm{mm}) \\
\text { Mean } \pm \mathrm{SD}\end{array}$ & $5.86 \pm 0.69$ & $4.38 \pm 0.41^{*}$ \\
\hline
\end{tabular}

${ }^{*} \mathrm{p}<0.01$ with $\mathrm{PICH}$ or $\mathrm{SAH}$ and $\mathrm{IVH}$, four with tumor and two with ischemic stroke (Table 2). The mean GCS was $11.9 \pm 4.4$.

There was a trend of wider ONSD in patients with either PICH or SAH with IVH compared to ONSD in $\mathrm{PICH}(\mathrm{p}=0.1)$ (Table 2). ONSD was $5.72 \pm 0.59 \mathrm{~mm}$ in patients with $\mathrm{PICH}$ and $6.20 \pm 0.65 \mathrm{~mm}$ in patients with either PICH or SAH with IVH $(\mathrm{p}=0.1)$. ONSD was $5.73 \pm 0.38 \mathrm{~mm}$ in patients with SAH compared to patients with either PICH or SAH with IVH $(\mathrm{p}=0.4)$.

Wider ONSD was observed in two patients with ischemic stroke (Table 2), while OND did not differ significantly between the ischemic stroke group and control group $(2.93 \pm 0.54 \mathrm{~mm}$ vs. $2.39 \pm 0.33 \mathrm{~mm}$; $\mathrm{p}>0.05)$.

The mean ONSD was $6.28 \pm 0.61 \mathrm{~mm}$ in coma patients $(\mathrm{GCS}<8)$ and $5.77 \pm 0.55 \mathrm{~mm}$ in other patients $(\mathrm{p}<0.05)$. We found no significant difference in OND between patients with GCS $<8$ and patients with GCS $\geq 8(2.7 \pm 0.38 \mathrm{~mm}$ vs. $2.41 \pm 0.22 \mathrm{~mm} ; \mathrm{p}>0.05)$.

Patients with favorable outcome $(\mathrm{mRS} \leq 3)(\mathrm{n}=10)$ had ONSD $5.64 \pm 0.61 \mathrm{~mm}$ compared to $5.94 \pm 0.77$ $\mathrm{mm}$ in patients with unfavorable outcome $(\mathrm{mRS}>3)$ $(\mathrm{n}=24)(\mathrm{p}=0.06)$.

\section{Discussion}

Our results showed enlarged ONSD in patients admitted to NICU for suspicion of raised ICP as compared to controls. There was no difference in OND between patients and controls. Such findings are in concordance with the findings of enlarged ONSD in

Table 2. Data on patients admitted to the neurological intensive care unit due to neurological emergency

\begin{tabular}{|c|c|c|c|c|c|}
\hline & $\begin{array}{l}\text { Primary } \\
\text { intracerebral } \\
\text { hemorrhage } \\
\mathrm{n}=8\end{array}$ & $\begin{array}{l}\text { Subarachnoid } \\
\text { hemorrhage } \\
n=8\end{array}$ & $\begin{array}{l}\text { Primary intracerebral } \\
\text { or subarachnoid hemorrhage } \\
\text { with intraventricular } \\
\text { hemorrhage } \\
\mathrm{n}=12\end{array}$ & $\begin{array}{l}\text { Ischemic } \\
\text { stroke } \\
n=2\end{array}$ & $\begin{array}{l}\text { Brain tumor } \\
\mathrm{n}=4\end{array}$ \\
\hline Age (years) & $68 \pm 12.5$ & $48.9 \pm 3.7$ & $62.5 \pm 17.3$ & $72 \pm 12.7$ & $63.3 \pm 20.9$ \\
\hline Gender (males) & $62.5 \%$ & $62.5 \%$ & $58.3 \%$ & $100 \%$ & $25 \%$ \\
\hline Glasgow Coma Score & 15 & 15 & 8 & $8.5 \pm 6.4$ & $13.5 \pm 3$ \\
\hline $\begin{array}{l}\text { ONSD }(\mathrm{mm}) \\
\text { Mean } \pm \text { SD }\end{array}$ & $5.72 \pm 0.65$ & $5.73 \pm 0.38$ & $6.2 \pm 0.65$ & $6.28 \pm 0.87$ & $5.15 \pm 0.95$ \\
\hline $\begin{array}{l}\mathrm{OND}(\mathrm{mm}) \\
\text { Mean } \pm \text { SD }\end{array}$ & $2.44 \pm 0.16$ & $2.43 \pm 0.14$ & $2.49 \pm 0.23$ & $2.93 \pm 0.54$ & $2.38 \pm 0.31$ \\
\hline
\end{tabular}

ONSD = optic nerve sheath diameter; OND = optic nerve diameter 
patients with TBI suspected to have raised $\mathrm{ICP}^{1,6}$. No difference was found in OND between patients with TBI and controls either ${ }^{1}$. In our study, the mean ONSD in stroke patients suspected to have raised ICP was $5.86 \pm 0.69 \mathrm{~mm}$. Diversities of cut-off value for raised ICP in TBI have been described, ranging from 5 to $6 \mathrm{~mm}$, with the most frequently reported ONSD between 5.7 and $5.9 \mathrm{~mm}^{17}$. In TBI with raised ICP (>20 mm Hg), ONSD of $5.86 \mathrm{~mm}^{1}, \mathrm{ICP}>20 \mathrm{~cm} \mathrm{H}_{2} 0$ ONSD $>5 \mathrm{~mm}^{2,7}$, or ONSD $>5.7 \mathrm{~mm}$ in coma patients with $\mathrm{GCS} \leq 8^{6}$ have been described. In our study, coma patients (GCS <8) had a mean ONSD of $6.28 \pm 0.61 \mathrm{~mm}$. In the literature, when neurocritical patients progressed to brain death, even without intracranial hypertension, showed higher $\mathrm{ONSD}^{6,16}$. After dramatic increase in ICP, ONSD in brain death had mean values above $7 \mathrm{~mm}^{6,15,16}$.

Two studies assessed values of ONSD measurement in stroke patients. Skoloudlik et al. ${ }^{11}$ found significantly enlarged ONSD in acute $\mathrm{ICH}$ patients compared to ischemic stroke patients, and the best cut-off point to predict ICH volume $>2.5 \mathrm{~cm}^{3}$ was relative ONSD enlargement of $>0.66 \mathrm{~mm}$. Göcken $e t$ $a l .{ }^{12}$ evaluated ONSD in ischemic stroke patients according to 4 Oxfordshire Community Stroke Project subgroups and found the highest right-left ONSD in the total anterior circulation infarction (TACI) group. Our study included only two ischemic stroke patients suspected to have raised ICP due to middle cerebral artery infarction, which is actually TACI group, having mean ONSD of $6.28 \pm 0.87 \mathrm{~mm}$.

Monitoring of patients with $\mathrm{ICH}$ demonstrated that significant enlargement of ONSD in hyperacute stage within 6 hours of stroke onset ${ }^{11}$ correlated with midline shift of the third ventricle seen on CT $\operatorname{scan}^{14}$. In settings where no invasive monitoring is feasible, ONSD enlargement may be a useful method for monitoring ICP increase.

Although mRS depends on multiple variables, we used it for rough assessment of favorable or unfavorable outcome. Other variables such as location of hematoma, which do not raise ICP, can have a huge impact. The study showed a trend of wider ONSD in patients with unfavorable outcome $(\mathrm{mRS}>3) \mathrm{com}^{-}$ pared to patients with favorable outcome. In early prediction of hypoxic encephalopathy after cardiac arrest, optic nerve sheath sonography was performed ${ }^{8}$. ONSD $\leq 5.4 \mathrm{~mm}$ was shown to be prognostic in the assess- ment of favorable outcome of GCS $\geq 4^{8}$. Further studies are needed to assess the value of ONSD in terms of prognostic outcome in stroke patients.

Sonography of the ONSD is a reliable tool for assessment of stroke patients admitted to the NICU. Increased ONSD but not OND was observed, compared to healthy controls. Increased ONSD was more pronounced in coma patients and in patients with brain hemorrhage with IVH. Increased ONSD was associated with unfavorable outcome. Further studies are needed to assess the value of ONSD in terms of prognostic outcome in neurological patients with different brain pathology.

\section{Acknowledgments}

The authors would like to acknowledge general support for conducting the study provided by Prof. Vanja Bašić Kes, Head of Department of Neurology and Prof. Vesna Vargek Solter, Head of Intensive Care Department.

\section{References}

1. Geeraerts T, Merceron S, Enhamou D, Vigue B, Duranteau J. Non-invasive assessment of intracranial pressure using ocular sonography in neurocritical care patients. Intensive Care Med. 2008;34:2062-7. doi: 10.1007/s00134-008-1149-x.

2. Kimberly HH, Shah S, Marill K, Noble V. Correlation of optic nerve sheath diameter with direct measurement of intracranial pressure. Academ Emerg Med. 2008;15:201-4. doi: 10.1111/ j.1553-2712.2007.00031.x.

3. Bäuerle J, Schuchardt F, Schroeder L, Egger K, Weigel M, Harloff A. Reproducibility and accuracy of optic nerve sheath diameter assessment using ultrasound compared to magnetic resonance imaging. BMC Neurology. 2012;13:187. doi: 10.1186/1471-2377-13-187.

4. Hassler W, Steinmetz H, Gawlowski J. Transcranial Doppler ultrasonography in raised intracranial pressure and in intracranial circulatory arrest. J Neurosurg. 1988;68:745-51.

5. Girisgin AS, Kalkan E, Kocak S, Cander B, Gul M, Semiz M. The role of optic nerve ultrasonography in the diagnosis of elevated intracranial pressure. Emerg Med J. 2007;24:251-4. doi: 10.1136/emj.2006.040931.

6. Geeraerts T, Launey Y, Martin L, Pottecher J, Vigue B, Duranteau J, Benhamou D. Ultrasonography of the optic nerve sheath may be useful for detecting raised intracranial pressure after severe brain injury. Intensive Care Med. 2007;33:1704-11. doi: 10.1007/s00134-007-0797-6.

7. Blaivas M, Theodoro D, Sierzenski PR. Elevated intracranial pressure detected by bedside emergency ultrasonography of the 
optic nerve sheath. Acad Emerg Med. 2003;10:376-81. doi: 10.1111/j.1553-2712.2003.tb01352.x

8. Ueda T, Ischida E, Kojima Y, Yoshikawa S, Yonemoto H. Sonographic optic nerve sheath diameter: a simple and rapid tool to assess the neurologic prognosis after cardiac arrest. J Neuroimaging. 2005;25:927-30. doi: 10.1111/jon.12246.

9. Lochner P, Brio F, Zedde ML, Sanguigni S, Coppo L, Nardone R, Naldi A, Sola D, Stolz E. Feasibility and usefulness of ultrasonography in idiopathic intracranial hypertension or secondary intracranial hypertension. BMC Neurology. 2016;16(1):85. doi: 10.1186/s12883-016-0594-3.

10. Fictner J, Ulrich C, Fung C, Knuppel C, Veitweber M, Jilch A, Schucht P, Ertl M, et al. Management of spontaneous intracranial hypotension - transorbital ultrasound as discriminator. J Neurol Neurosurg Psychiatry. 2016;87:650-5. doi: 10.1136/ jnnp-2015-310853.

11. Skoloudlik D, Herzig R, Fadrna T, Bar M, Hradilek P, Roubec M, Jelinkova M, Sanak D, Kral M, Chmelova J, Herman M, Langova K, Kanovsky P. Distal enlargement of the optic nerve sheath in the hyperacute stage o intracerebral haemorrhage. $\mathrm{Br}$ J Ophthalmol. 2011;95:217-21. doi: 10.1136/bjo.2009.172890.

12. Göcken E, Caltekin I, Savrun A, Korkmaz H, Savrn ST, Yildirim G. Alterations in optic nerve sheath diameter according to cerebrovascular disease sub-groups. Am J Emerg Med. 2017; 35(11):1607-11. doi: 10.1016/j.ajem.2017.04.073.

13. Bäuerle J, Niesen WD, Egger K, Buttler KJ, Reinhard M. Enlarged optic nerve sheath in aneurysmal subarachnoid hemorrhage despite normal intracranial pressure. J Neuroimaging. 2016;26:194-6. doi: 10.1111/jon.12287.

14. Lochner P, Mader C, Nardone R, Tezzon F, Zedde ML, Malferrari G, Brigo F. Sonography of the optic nerve sheath beyond the hyperacute stage of intracerebral hemorrhage.J Ultrasound. 2014;17:225-8. doi: 10.1007/s40477-014-0069-6.

15. Lovrencic-Huzjan A, Sodec Simicevic D, Martinic Popovic I, Bosnar Puretic M, Vukovic Cvetkovic V, Gopcevic A, Vucic M, Rode B, Demarin V. Ultrasonography of the optic nerve sheath in brain death. Perspect Med. 2012;1:414-6. doi: 10.1016/j. permed.2012.02.060.

16. Toscano M, Spadetta G, Pulitano P, Rocco M, Di Piero V, Mecarelli O, Vincenzini E. Optic nerve sheath diameter ultrasound evaluation in intensive care unit: possible role and clinical aspects in neurological critical patients' daily monitoring. Biomed Res Int. 2017:1621428. doi: 10.1155/2017/1621428.

17. Bäuerle J, Nedelmann M. B-mode sonography of the optic nerve in neurological disorders with altered intracranial pressure. Perspect Med. 2012;1:404-7. doi: 10.1016/j.permed. 2012.01.001.

Sažetak

\title{
SONOGRAFIJA OVOJNICE OPTIČKOG ŽIVCA JE OBEĆAVAJUĆI ALAT U PROCJENI PORASTA INTRAKRANIJSKOG TLAKA U BOLESNIKA LIJEČENIH U NEUROLOŠKOJ INTENZIVNOJ SKRBI
}

\author{
A. Lovrenčić-Huzjan, M. Bosnar-Puretić, I. Hustić, I. Kobasić, M. Budišić, L. Corić i M. Roje-Bedeković
}

Povećanje promjera ovojnice optičkog živca (POOŽ) vidljivo je u bolesnika s traumatskom ozljedom mozga s povećanim intrakranijskim tlakom. Cilj je bio procijeniti njegovu vrijednost u neuroloških bolesnika sa sumnjom na porast intrakranijskog tlaka. Analizirani su klinički podaci, nalazi slikovnog prikaza i ishod hospitalizacije. Bolesnici su podijeljeni u skupine prema moždanoj patologiji i razini svijesti prema rezultatu na Glasgow Coma Score (GCS). Nepovoljan ishod procijenjen je modificiranom Rankinovom skalom $(\mathrm{mRS})>3$. Podaci okularne sonografije u akutnim uvjetima uspoređeni su s podacima 100 zdravih kontrolnih osoba. Vrijednosti su prikazane kao srednje vrijednosti i standardne devijacije. Usporedba između skupina provedena je Studentovim t-testom. Za analizu su bili prikladni podaci 34 bolesnika ( $63 \pm 16$ godina): 8 primarnih intracerebralnih krvarenja (PICK), 8 subarahnoidnih krvarenja (SAK), 12 PICK ili SAK s intraventrikulskim krvarenjem

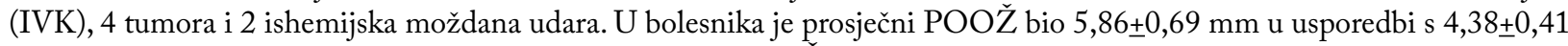

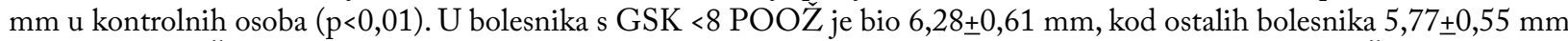
$(\mathrm{p}<0,05)$. POOŽ u PICK je bio 5,72 $\pm 0,59 \mathrm{~mm}$, a kod PICK/SAK s IVK 6,20 $\pm 0,65 \mathrm{~mm}(\mathrm{p}=0,1)$. POOŽ u SAK je bio $5,73 \pm 0,38 \mathrm{~mm}$ u usporedbi s PICK/SAK s IVK $(\mathrm{p}=0,05)$. Nije bilo statistički značajne razlike u POŽ između bolesnika i kontrolnih osoba $(2,48 \pm 0.28 \mathrm{~mm}$ odnosno $2,39 \pm 0,33 \mathrm{~mm} ; \mathrm{p}>0,05)$. Izrazito je povećanje POOŽ zabilježeno u bolesnika s ICK ili SAK s IVK te u bolesnika s GSK <8.Povećani POOŽ bio je povezan s lošim neurološkim ishodom $(\mathrm{mRS}>3)$.

Ključne riječi: Vidni živac; Moždane ozljede, traumatske; Intrakranijski tlak; Ultrazvuk 